\title{
The Analysis on Financial Performance of the Industrial Chain and Spatial Effect for China's New Energy Automobile
}

\author{
Hongbo Zhang ${ }^{1, a}$ Ming $\mathrm{Hu}^{1, b}$ Hongming Zhang ${ }^{2, \mathrm{c}}$ \\ 1. Business School, Nanjing University of Information Science \& Technology. Ningliu Road 219\# \\ Nanjing City Jiangsu Province China (210044) \\ 2. School of Economics, Shenyang University. Wanghua South Street21\#, Dadong District, \\ Shenyang City Liaoning Province China (110044) \\ azhanghongbo100@163.com, b854744253@qq.com, chongming-0411@163.com
}

\begin{abstract}
Key words: Electric vehicles; Financial performance; Business chain; Distribute
Abstract: In recent years, the global energy supply tends to be tight, the environmental problem causes the widespread concern, the traditional automobile malpractice gradually appears, the government pays more and more attention to the energy saving and emission reduction, has brought the new opportunity to the new energy automobile industry. After a period of development. China's electric vehicle industry layout and profit model has gradually stabilized. Which part of the industrial chain is the economic performance of electric vehicles generated, and is the regional layout reasonable? The above problems are studied in this paper. This paper first summarizes the theories and methods of performance evaluation at home and abroad, analyzes the performance of 61 electric vehicle listed companies in China, and then analyzes the performance of 61 electric vehicle listed companies. The data processing in 2012-2016 shows that the performance of enterprises in the upstream and eastern regions of the industrial chain is relatively better. Finally, based on empirical evidence and previous literature, five suggestions are put forward for the new energy automobile industry to improve the performance level.
\end{abstract}

\section{Introduction}

In 2017, China's apparent oil consumption reached 590 million tons, a growth rate of $5.9 \%$ from the previous year, an increase of 3 percentage points over the previous year, which was the highest point since 2011; the net oil import volume reached throughout the year 3.96 billion tons, an increase of $10.8 \%$ over the previous year, an increase of 1.2 percentage points over the previous year. In 2017, China's crude oil imports exceeded the United States, becoming the world's largest crude oil importer for the first time, and its dependence on foreign oil rose to $67.4 \%$. Once the international situation changes, our country will be greatly affected. The government is increasingly aware that electric vehicles should become a new direction for the development of the automotive industry. From the definition of electric vehicles, it can be seen that the new energy automobile industry is a comprehensive and comprehensive industry. It not only needs the experience of the traditional automobile manufacturing industry, but also can not be separated from the high-tech support. The linkage is larger and also brings great Risky. Therefore, in the current situation of high $\mathrm{R} \& \mathrm{D}$ costs for electric vehicles, in order to truly realize the long-term good operation of electric vehicles, good financial performance is required. By studying the financial performance of the listed companies of China New Energy Automobile, we can get a general understanding of the status quo and trends of this industry, so that investors can better predict returns and rational investment; for managers, they can become familiar with the financial status of the company and find out Factors affecting company performance, finding problems and risks, and thus targeted structural optimization, analyzing the situation of other companies, will also help the company learn from the management model of leading companies, and then combine the characteristics of the company to innovate and achieve beyond. 


\section{Literature Review}

\section{Related Theories and Model of Financial Performance Evaluation}

In the field of strategic management, "performance" is a word which is quite important and never out of date. It also produces different research directions. The first one is the theoretical model. At the beginning of the 20th century, DuPont Co., Ltd. made a comprehensive analysis of the financial status with several major financial ratios, and broke the ROE into three parts: profitability, total asset turnover, and financial leverage. It evaluated separately from three aspects: profitability, operational capability and capital structure, which established the DuPont financial analysis system. In 1971, Melnes of the United States made important contributions in the performance evaluation index system. Based on the investigation of the performance evaluation system of multinational corporations in the United States, he published the "Multinational Corporation Financial Control - Empirical Survey" and pointed out that performance appraisal index which is the most commonly used is the return on investment, and the earnings per share is also an important indicator of the company's performance. In 1979, Person and Lessig conducted a questionnaire survey of 400 multinational companies and found that the financial performance evaluation indicators used by these companies include sales profit rate, EPS, cash flow, and Internal rate of return (IRR), etc.

In the 1990s, the American scholar Stewart proposed the concept of economic value added, which means that when the company's profit is higher than the cost of capital (including equity cost and debt cost), it will create value for shareholders. This theory fully considers the cost of capital and replaces traditional accounting profits with economic profits, which makes the assessment of financial performance of the company more accurate; but EVA indicators are short-term financial indicators. On the one hand, it is easy for managers to focus only on the improvement of their own indicators during their term of office, regardless of the long-term development plan. On the other hand, it does not fully reflect the non-financial information of the company.

During the same period, basing on the theory of balanced scorecard management system (BSC), Kaplan and Norton analyzed corporate performance based on the system from four perspectives (innovation and learning, business processes, customers, finance).They found that analysis combined with financial Non-financial and non-financial measurement methods can comprehensively reflect the business status of the company and also help to evaluate the organization's forward-looking investment. In addition, foreign media for the performance evaluation of listed companies is also very enthusiastic. From 1955, Fortune magazine has ranked global listed companies based on the company's total annual sales revenue, and has 500 listed companies with the largest total annual sales revenue. This is the "Global 500". At the same time, it also sets some auxiliary indicators such as total profit, main business profit rate, etc., and conducts multiple parallel single-indicator rankings according to their size, listing the Top 50.

\section{Research on the Factors of Financial Performance}

In addition to deepening and innovating theories and models, many scholars have explored the influencing factors of performance. Eva (2010) believes that environmental regulations will affect the company's investment in environmental protection, and thus have an impact on the financial performance of the company. Empirical analysis is also conducted on the results of 64 of the past 37 empirical studies. The possibility of negative links between financial performances is significant. Andrea et al.(2011) found that ownership structure, company size and diversification, geographic location and other factors have different degrees of impact on the performance of Italian water company; Aigbe Akhigbe (2013) is based on the bank holding company as the research object, which proved the transparency High bank holding companies have better general financial performance; these are objective factors, while HS Rohitha et al. (2012), Julia C. et al. (2016) focus on human and behavior-related factors. Emphasizing the importance of management systems and organizational culture, and conducting in-depth studies based on Sri Lankan peasant companies and Spanish industrial companies, the results show that corporate culture that promotes positive values and can increase employee participation stimulates innovation, which has a positive impact on 
performance. Zhang Qixiu's (2017) research focuses on social responsibility. She believes that the company is an open whole, and based on the relevant theory and the triple performance standards proposed by Wen-Ping Wen, it analyzes the performance of corporate social responsibility, including the employees' Benefits, impact on the surrounding environment, etc. This study enriches the content of performance evaluation.

Research in the new energy automotive industry has focused on policy-related research. Luo Shaowen (2008), Zeng Yaoming (2011), and Wang Tao (2013) are very concerned about the impact of policies on electric vehicles, making further analysis of China's economic environment combining with actual, and at the same time comparing China's relevant support policies with foreign countries, for Industry development provides strategic advice of electric vehicles in China. Tessa T. et al. (2016) found that the German government's supportive policies for electric vehicles focused on road passengers and neglected freight transport. Therefore, the opinions of policy makers and electric freight vehicle users on 23 related policies in Europe were collected. There is a high possibility of inconsistency among the groups, according to which they believe that policy measures should not restrict cargo electric vehicles in government tenders; Marcello et al. (2017) explore the decline in battery costs in the United Kingdom and California on electric The automobile policy finds that the current policy generally focuses on accelerating electrification, and it pays little attention to the cost of specific types of electric vehicles and charging infrastructure deployed. Therefore, it provides suggestions for the formulation of policies from the perspective of the electrification risk of the transportation industry. Timothy M. Sweda et al. (2017) found that for electric vehicles, the battery status and the availability of charging infrastructure is very important. Therefore, the problem of finding the optimal adaptive routing and charging strategy for electric vehicles in the road network is studied and the policy recommendations were proposed from the perspective of practicality.

The above documents are all devoted to the study of the financial performance of electric vehicles listed companies themselves or the rationality of national and corporate policies. However, there are few studies on the influencing factors. Based on these articles, this article will analyze the business chain and the spatial effects of listed companies operating electric vehicles.

\section{Financial Situation of China's Electric Vehicle Listed Companies}

Electric buses can return funds quickly due to government purchases, but the market demand for electric cars is not wide. There may be a long time between the successful development of a new electric vehicle and real gains. The industry's overall capital turnover capacity development is uneven, the longer the payback period, the smaller the possibility of increasing profits, eventually leading to deterioration of the operating industry, and even let the company go bankrupt. In the life cycle theory, the listed companies of electric vehicles in China are still in the growth period. The nature of high-tech enterprises requires companies to invest high research and development expenses. Because the relevant technologies are not yet mature, some manufacturing and installation equipments need to be imported in large quantities. Equipment maintenance also requires the hiring of professional and technical personnel or outsourcing to other companies. The company's hi-tech personnel training funds and product R\&D funds are also a huge expense.

\section{Empirical Researches}

\section{Samples, Data and Assumptions}

Since the electric vehicle itself does not have an independent industry category in the list of listed companies, this article starts with the components of China's electric vehicles, and finds 60 nonferrous metal mining enterprises and 92 automobile manufacturing enterprises in the list of listed companies. By entering into the company's official website to search and screen one by one, 63 listed companies for electric vehicles related to electric vehicles, continuing operations for more than five years, no abnormal or continuous loss for three consecutive years, and full disclosure of annual reports were left. These were listed on the Hong Kong stock market. The relevant research 
data were incomplete and should be removed.

In the end, 61 electric vehicle listed companies can be used as research objects for data processing. This paper has also obtained industry information and basic data of companies from the information disclosure of the Automobile Industry Association official website, the Shanghai Stock Exchange, and the Shenzhen Stock Exchange. The database of Tai'an has obtained relevant indicators. The operating targets of electric vehicles listed companies can be roughly divided into the following four categories: resource extraction and collection, manufacturing of important parts, assembly or sales of vehicles, and follow-up maintenance, and research and development of charging piles. It can be seen as four links of a complete industrial chain. According to this

Assumption 1: The location of electric vehicle listed companies in the industry chain will have an impact on performance.

Due to the constraints of resource distribution, population density, and other objective factors, most of China's important energy bases are located in the northwest. For a long time, the energy pattern and flow of West-to-East power transmission, West-to-East gas transmission, and North-to-South coal transportation have formed. The country also supports Encourage entrepreneurs to conduct business activities in the northwest region to promote the local economy. However, after the economy entered the new normal, the market in major energy-consuming regions shrank the dependence and enthusiasm on the external energy sources of the receiving regions generally declined, and the conflicts of interest between energy delivery and receiving regions intensified. So this paper proposes

Assumption 2: The area where electric vehicle listed companies are located will have an impact on performance.

In addition, regarding performance measurement indicators, Chen Qingyun believes that from the summary of more than a dozen scholarly influential articles, the most frequently used measure of performance is the ROA (Return on Total Assets), so this article uses ROA. To represent the performance of the company, select the panel data for 2012-2016 to explore whether the industry chain or region influences the performance of electric vehicles listed companies, specifically through the following model:

$$
\begin{aligned}
& \operatorname{ROA}_{i, t}=\alpha_{0}+\alpha_{1} \operatorname{POS}_{i, t}+\alpha_{3} \operatorname{LEV}_{i, t}+\alpha_{4} A G E_{i, t}+\alpha_{5} \operatorname{SIZE}_{i, t}+\varepsilon \\
& \operatorname{ROA}_{i, t}=\alpha_{0}+\alpha_{1} \operatorname{REGION}_{i, t}+\alpha_{3} L E V_{i, t}+\alpha_{4} A G E_{i, t}+\alpha_{5} \operatorname{SIZE}_{i, t}+\varepsilon
\end{aligned}
$$

Among the equations, POS is the position in the industry chain, and there are 5 dummy variables, namely POS1: when it is in the position of upstream resource collection, it takes 1; otherwise, it takes 0; POS2: when it is in important component manufacturing, it takes 1; otherwise, POS3: when 1 in vehicle assembly or sales, otherwise 0 ; POS4, 1 in subsequent maintenance, 1 in charge of R\&D, otherwise 0; POS5: 1 in two or more positions at the same time, otherwise 0. REGION is a total of 5 position dummy variables, REGION1 REGION2 REGION3 REGION4 REGION5, which respectively represent the east, west, south, north, and middle of our country; SIZE is the natural assets of total assets represent the size of the company, LEV is the debt ratio, AGE is the age of listing for the company (Table 1). 
Table 1 Variable Definition and Description

\begin{tabular}{cc} 
Variable & Description \\
\hline SIZE & assets \\
LEV & asset-liability ratio \\
AGE & The age of listed companies \\
POS & position in the business chain \\
POS1 & resource collection \\
POS2 & important component manufacturing \\
POS3 & vehicle assembly or sales \\
POS4 & subsequent maintenance \\
POS5 & in two or more positions at the same time \\
\hline REGION & region in China \\
\hline REGION1 & eastern \\
REGION2 & western \\
REGION3 & southern \\
REGION4 & northern \\
REGION5 & middle of China \\
\hline
\end{tabular}

\section{Descriptive Statistical Analysis}

Table 2 shows the descriptive statistics of the explanatory variables ROA and each control variable, and records the mean, median, minimum, maximum, and standard deviation of each variable. As can be seen from the table, the average ROA is 0.035 , and the median is 0.031 , indicating that the average return on total assets in the model is $3.5 \%$. The maximum value is $14.6 \%$, and the minimum value is $-16.7 \%$. The performance of the sample companies is both good and bad, which also confirms the current situation of the development of China's new energy automotive industry companies, and the sample selection in this paper is more reasonable. LEV is the asset-liability ratio, with a maximum of $86.4 \%$ and a minimum of $14.1 \%$. This shows that companies with high assetliability ratios in the sample also have low-level liabilities, but the average value is $54.1 \%$. Overall, the sample is 61 . The company's asset-liability ratio is still high, exceeding 50\%. AGE represents the company's market-to-market age, with a maximum of 68 , a minimum of 6 , and a median of 24 , indicating that the 61 companies in this book have a variety of life cycles (primary, growing, mature, and recessionary), and most of them have reached maturity.

Table 2 Descriptive statistics of the explanatory variables ROA and control variables (61 companies, 305 observations, 2012-2016)

\begin{tabular}{lccccc} 
& average & median & $\begin{array}{c}\text { Standard } \\
\text { deviation }\end{array}$ & $\begin{array}{c}\text { minimu } \\
\mathrm{m}\end{array}$ & maximum \\
\hline ROA & 0.035 & 0.031 & 0.04 & -0.167 & 0.146 \\
LEV & 0.541 & 0.561 & 0.17 & 0.141 & 0.864 \\
SIZE & 23.182 & 23.167 & 1.32 & 20.425 & 27.104 \\
AGE & 24.730 & 24.000 & 6.89 & 6.000 & 68.000 \\
\hline
\end{tabular}

Table 3 shows the location of the industry chain and the distribution of the regions. From the statistical point of view of Table 3, the number of companies with an industrial chain located in upstream resource extraction and processing accounts for the majority, which is 18 . At the same time, there are only two of the two locations and are in follow-up maintenance, and the research and development positions of the charging piles are limited. From the perspective of regional 
distribution, the eastern region accounts for nearly one-third of the 19 samples, while the western region has only 2 samples. Judging from the current situation of the development of electric vehicles in China, this is in line with objective reality. Although the western region has low land costs, low labor costs, and a large number of mineral deposits, the environment is harsh and transportation is inconvenient. Most companies choose to set up their headquarters in a bustling urban area. . In addition, the total amount of R\&D charging piles is not large. On the one hand, it may be a technical limitation and there is no relevant $R \& D$ experience. On the other hand, the electric vehicle itself may not have a large market demand. Therefore, subsequent maintenance and charging equipment are not very The big market makes this part of the company unable to grow large-scale, and there are not many successful listings.

Table 3 Business Chain Location and Regional Distribution

\begin{tabular}{|c|c|c|c|c|c|c|}
\hline & total & upstream & $\begin{array}{l}\text { important } \\
\text { component }\end{array}$ & vehicle & $\begin{array}{c}\text { Mainte- } \\
\text { nance }\end{array}$ & $>1$ \\
\hline $\begin{array}{l}\text { position of } \\
\text { business chain }\end{array}$ & 61 & 18 & 16 & 13 & 10 & 4 \\
\hline & & eastern & western & southern & northern & middle \\
\hline region & 61 & 19 & 2 & 19 & 11 & 10 \\
\hline
\end{tabular}

\section{Correlation Test}

Table 4 shows the Pearson correlation coefficient matrix of the control variables. It can be seen that each correlation coefficient value is less than 0.8 and there is no obvious multicollinearity problem among the control variables. And from the result point of view, LEV and ROA were significantly negatively correlated, indicating that the higher the debt ratio, the performance of the company tends to be relatively poor; SIZE and ROA are positively correlated, and the larger the company's size, the more often it shows a better performance. The AGE and ROA are not significant, indicating that the growth of the sample companies does not have a significant impact on performance.

Table 4 Pearson Correlation Coefficient Matrix of Control Variables ${ }^{*}$ means that $10 \%$ level is significant, $* *$ means $5 \%$ level is significant, $* * *$ means $1 \%$ level is significant)

\begin{tabular}{lcccc}
\hline & ROA & LEV & SIZE & AGE \\
\hline ROA & 1.000 & & & \\
LEV & $-0.178^{* *}$ & 1.000 & & \\
SIZE & $0.146^{* *}$ & $0.452^{* * *}$ & 1.000 & \\
AGE & 0.042 & $0.240^{* * *}$ & $0.160^{* *}$ & 1.000 \\
\hline
\end{tabular}

Table 5 shows the Pearson correlation coefficient matrix of the location, industry chain location and ROA. From this we can see that pos1 (i.e. the upstream location) is significantly positively correlated with the ROA, indicating that the company's total assets return rate is higher in the upstream location resource extraction and collection, and pos4 It is significantly negatively correlated with ROA, indicating that the company's total assets return rate is lower in the subsequent maintenance and R\&D positions of charging piles, while the position of other industry chains has not yet shown a significant relationship. Region 1 is significantly positively correlated with ROA, indicating that the return rate of total assets in the eastern region is relatively high, and region4 is significantly negatively correlated with ROA, indicating that the performance of northern enterprises is relatively poor, while the correlation between other regions and ROA is not obvious. 
Table 5 Pearson Correlation Coefficient Matrix of Regional, Business chain location and ROA

\begin{tabular}{|c|c|c|c|c|c|c|c|c|c|c|c|}
\hline & 1 & 2 & 3 & 4 & 5 & 6 & 7 & 8 & 9 & 10 & 11 \\
\hline roa & 1.000 & & & & & & & & & & \\
\hline pos1 & $0.301^{* * *}$ & 1.000 & & & & & & & & & \\
\hline pos2 & -0.015 & $0.326^{* * *}$ & 1.000 & & & & & & & & \\
\hline pos3 & 0.050 & $0.224^{* * *}$ & $0.468^{* * *}$ & 1.000 & & & & & & & \\
\hline pos 4 & $0.247^{* * * *}$ & $-0.138^{*}$ & $0.287^{* * *}$ & $0.197^{* * * *}$ & 1.000 & & & & & & \\
\hline pos5 & 0.040 & $-0.138^{*}$ & $0.287^{* * *}$ & $0.197^{* * *}$ & -0.121 & 1.000 & & & & & \\
\hline region1 & $0.264^{* * *}$ & $0.274^{* * *}$ & $0.133^{*}$ & 0.011 & $0.131^{*}$ & -0.055 & 1.000 & & & & \\
\hline region2 & -0.045 & $0.172^{* *}$ & -0.044 & 0.062 & -0.103 & -0.103 & $0.206^{* * *}$ & 1.000 & & & \\
\hline region3 & -0.002 & $0.213^{* * *}$ & 0.023 & -0.113 & 0.054 & $-0.168^{* *}$ & $0.335^{* * *}$ & $-0.143^{*}$ & 1.000 & & \\
\hline region4 & $0.327^{* * *}$ & 0.011 & -0.118 & 0.048 & $0.168^{* * *}$ & $0.276^{* * *}$ & $0.335^{* * *}$ & $-0.143^{*}$ & $0.233^{* * *}$ & 1.000 & \\
\hline region5 & 0.042 & -0.016 & -0.033 & 0.008 & 0.029 & 0.029 & $0.364^{* * * *}$ & $0.156^{* *}$ & $0.254^{* * *}$ & $0.254^{* * *}$ & 1.000 \\
\hline
\end{tabular}

\section{Multiple Regression Analysis}

Table 6 shows the multiple regression analysis results between the position of the industrial chain and the ROA. The F value can pass the $1 \%$ level of significance test, indicating that the model's explanatory power is better, and the hypothesis 1 is established. From the result point of view, the POS 1 coefficient is significantly positively correlated at the $1 \%$ level, which shows that compared with other situations; the total assets return rate is higher for companies that are exploiting resources in the upstream location. The coefficients of POS2, POS3, and POS5 are not significant, indicating that companies that are in the manufacturing of important parts, assembly or sales of vehicles, and are located in the same position in the two industry chains do not have higher return on total assets than other locations. The coefficient of POS4 is significantly negatively correlated at the $1 \%$ level, which indicates that compared with other cases, the companies with subsequent maintenance and research and development of charging piles have lower total asset returns. In terms of control variables, both LEV and ROA in the model were significantly negatively correlated at the $1 \%$ level. Both SIZE and ROA were significantly positively correlated at the $1 \%$ level. The higher the assetliability ratio was, the worse the performance of the company was, and the larger the company's size was, the better the company's performance was. Well, this is consistent with the characteristics of general literature studies and asset-liability ratios

Table 6 Multiple Regression Analysis Between Position of Industry Chain and ROA

\begin{tabular}{|c|c|c|c|c|c|}
\hline & (1) & (2) & (3) & (4) & (5) \\
\hline & ROA & ROA & ROA & ROA & ROA \\
\hline \multirow[t]{2}{*}{ POS1 } & $0.043^{\text {**** }}$ & & & & \\
\hline & $(3.74)$ & & & & \\
\hline \multirow[t]{2}{*}{ POS2 } & & 0.002 & & & \\
\hline & & $(0.37)$ & & & \\
\hline \multirow[t]{2}{*}{ POS3 } & & & 0.010 & & \\
\hline & & & (1.21) & & \\
\hline \multirow[t]{2}{*}{ POS4 } & & & & $-0.043^{* * *}$ & \\
\hline & & & & $(-4.98)$ & \\
\hline \multirow[t]{2}{*}{ POS5 } & & & & & -0.009 \\
\hline & & & & & $(-1.26)$ \\
\hline \multirow[t]{2}{*}{ LEV } & $-0.090^{* * *}$ & $-0.083^{* * *}$ & $-0.090^{* * *}$ & $-0.074^{* * *}$ & $-0.086^{* * *}$ \\
\hline & $(-4.31)$ & $(-3.58)$ & $(-3.55)$ & $(-3.12)$ & $(-3.65)$ \\
\hline \multirow[t]{2}{*}{ SIZE } & $0.010^{* * *}$ & $0.010^{* * *}$ & $0.009^{* * *}$ & $0.011^{* * *}$ & $0.010^{* * *}$ \\
\hline & (4.73) & $(4.41)$ & $(4.25)$ & $(5.07)$ & (4.34) \\
\hline \multirow[t]{2}{*}{ AGE } & $0.001^{* *}$ & 0.000 & 0.000 & $0.001^{* *}$ & 0.001 \\
\hline & $(2.28)$ & (1.19) & $(1.15)$ & $(2.38)$ & $(1.24)$ \\
\hline \multirow[t]{2}{*}{ Constant term } & $-0.152^{* * *}$ & $-0.156^{* * *}$ & $-0.141^{* * *}$ & $-0.208^{* * *}$ & $-0.165^{* * *}$ \\
\hline & $(-3.71)$ & $(-3.54)$ & $(-3.29)$ & $(-4.73)$ & $(-3.51)$ \\
\hline$N$ & 305 & 305 & 305 & 305 & 305 \\
\hline
\end{tabular}




\begin{tabular}{lccccc}
$R^{2}$ & 0.209 & 0.102 & 0.110 & 0.179 & 0.105 \\
adj. $R^{2}$ & 0.191 & 0.082 & 0.090 & 0.161 & 0.085 \\
$\mathrm{~F}$ & $12.189^{* * * *}$ & $7.666^{* * *}$ & $7.841^{* * *}$ & $18.019^{* * *}$ & $7.455^{* * *}$ \\
\hline
\end{tabular}

Table 7 Robustness Test (1)

\begin{tabular}{cc} 
& ROE \\
POS1 & $0.038^{* * *}(3.56)$ \\
POS2 & $0.001(0.16)$ \\
POS3 & $0.009(1.12)$ \\
POS4 & $-0.029^{* *}(-2.73)$ \\
POS5 & $-0.011(-1.04)$ \\
\hline
\end{tabular}

Table 8 shows the results of a multiple regression analysis of the relationship between the region and ROA. The F value can pass the $1 \%$ level of significance test, and Hypothesis 2 holds. At the same time, since another important indicator of corporate performance is ROE, ROE is used for robustness analysis. The results (Table 9) indicate that the model has better explanatory power. The coefficient of REGION1 was significantly positively correlated at $1 \%$ level, indicating that compared with other regions, companies in the eastern region had higher asset returns and better performance; REGION4 coefficients were significantly negatively correlated at $1 \%$, indicating that compared to other regions, The northern region's corporate assets have a lower rate of return. The other variables REGION2, REGION3, and REGION5 have no significant coefficients, indicating that the performance of the companies in the western, southern, and central regions does not show any significant differences.

Table 8 Multivariate Regression Analysis of the Relationship between the Region and ROA

\begin{tabular}{|c|c|c|c|c|c|}
\hline & $(1)$ & $(2)$ & (3) & (4) & (5) \\
\hline & ROA & ROA & ROA & $\mathrm{ROA}$ & ROA \\
\hline \multirow[t]{2}{*}{ REGION1 } & $0.025^{* * *}$ & & & & \\
\hline & $(4.51)$ & & & & \\
\hline \multirow[t]{2}{*}{ REGION2 } & & -0.013 & & & \\
\hline & & $(-1.07)$ & & & \\
\hline \multirow[t]{2}{*}{ REGION3 } & & & -0.001 & & \\
\hline & & & $(-0.16)$ & & \\
\hline \multirow[t]{2}{*}{ REGION4 } & & & & $-0.046^{* * * *}$ & \\
\hline & & & & $(-4.89)$ & \\
\hline \multirow[t]{2}{*}{ REGION5 } & & & & & 0.010 \\
\hline & & & & & (1.33) \\
\hline \multirow[t]{2}{*}{ LEV } & $-0.080^{* * *}$ & $-0.088^{* * *}$ & $-0.084^{* * *}$ & $-0.076^{* * *}$ & $-0.088^{* * *}$ \\
\hline & $(-3.66)$ & $(-3.98)$ & $(-3.60)$ & $(-3.52)$ & $(-3.67)$ \\
\hline \multirow[t]{2}{*}{ SIZE } & $0.011^{* * *}$ & $0.010^{* * *}$ & $0.010^{* * *}$ & $0.014^{* * *}$ & $0.011^{* * *}$ \\
\hline & $(4.74)$ & $(4.51)$ & $(4.55)$ & $(5.55)$ & $(4.48)$ \\
\hline \multirow[t]{2}{*}{ AGE } & 0.001 & 0.001 & 0.0001 & -0.0001 & 0.001 \\
\hline & $(1.40)$ & (1.28) & (1.10) & $(-0.75)$ & (1.26) \\
\hline \multirow[t]{2}{*}{ Constant term } & $-0.184^{* * *}$ & $-0.164^{* * *}$ & $-0.164^{* * *}$ & $-0.230^{* * *}$ & $-0.175^{* * *}$ \\
\hline & $(-4.27)$ & $(-3.62)$ & $(-3.76)$ & $(-4.79)$ & $(-3.74)$ \\
\hline$N$ & 305 & 305 & 305 & 305 & 305 \\
\hline$R^{2}$ & 0.195 & 0.132 & 0.126 & 0.267 & 0.134 \\
\hline adj. $R^{2}$ & 0.158 & 0.093 & 0.086 & 0.234 & 0.095 \\
\hline $\mathrm{F}$ & $9.959^{* * *}$ & $6.577^{* * * *}$ & $5.228^{* * *}$ & $8.333^{* * *}$ & $5.110^{* * *}$ \\
\hline
\end{tabular}


Table 9 Robustness Test (2)

\begin{tabular}{lc} 
& ROE \\
\hline REGION1 & $0.034^{* * *}(4.28)$ \\
REGION2 & $-0.009(-1.07)$ \\
REGION3 & $-0.003(-0.08)$ \\
REGION4 & $-0.025^{* * *}(-4.34)$ \\
REGION5 & $0.010(1.23)$ \\
\hline
\end{tabular}

\section{Conclusions and Suggestion}

The new energy automobile industry is one of the strategic emerging industries that have been intensively cultivated and developed during the "13th Five-Year Plan" period in China. Currently, the "One Belt and One Road" policy still leaves much room for the development, production, and operation of electric vehicles. The energy automotive industry has shown a rapid growth trend, and it has its own characteristics of high risk and high profitability. Therefore, both investors and operators are very concerned about the performance level of electric vehicle companies. Therefore, for listed companies of electric vehicles, it is very important to understand what factors affecting company performance and how these factors affect performance. From the analysis and analysis results of this paper, the company's asset-liability ratio, scale, position in the industry chain and the company's location will have an impact on performance. The higher the asset-liability ratio, the higher the company's general performance is. The larger the scale, generally speaking, the performance of the company will be high; in the entire new energy automotive industry chain, the company's performance in upstream resource extraction and collection is considerable, but the follow-up maintenance and the company's performance in the development of charging piles is not good; In terms of regional distribution, most companies in the eastern part of China have high performance, while northern regions have poor performance.

Based on the above conclusions, this paper concludes that: (1) the development of electric vehicle enterprises in China is diverse, and most of them are concentrated in the manufacturing process of important intermediate components in the industrial chain. Although for a new energy automobile, the important component is the battery part, but on the one hand, the core technology development of the battery part requires a lot of manpower, material and financial resources. On the other hand, R\&D to sales often takes a long time and will give the company funds. Inconvenience caused by turnover, the performance of these companies will be relatively low. At present, the upstream position of the industry chain, that is, the battery-related resources mining and collection enterprise performance is relatively good, so companies should fully assess their own ability, a reasonable position, and keep corporate liabilities at a relatively low level to cope with the risk from time to time. (2) Enterprises at the end of the new energy automobile industry chain, which mainly conducts follow-up maintenance and research and development of charging equipment, have generally low performance. They should strengthen cooperation with enterprises in other sectors, expand their markets, and increase their visibility; special charging piles and charging Station construction often requires high building materials costs and land a rent, which also makes the charging price relatively high. If the price difference between the peak and the valley is fully and reasonably used to charge and store the charging piles, and according to the type of electric vehicles Assortment, step charging charge, can make the charging price more humane. (3) China's economic development Overall, the eastern region is superior to the western region, especially the eastern coastal areas and along the Yangtze River. Although land prices, labor costs, and competition are fiercer, there are also talented people, high levels of urban development, and developed road networks. Many companies in the same industry chain, if they cooperate in the long run, are still conducive to avoiding weaknesses, broadening the market, and improving performance. (4) As electric vehicles in our country are still a relatively distant thing from consumers, there are many 
unknowns, so new energy automobile companies can launch experience services in conjunction with the sharing economy, and can also share cars through test drive, lease, and new energy. The distance between electric vehicles and the public is well drawn. (5) In terms of policies, in addition to the specific goals of the battery R\&D department of electric vehicles with subsidy or funding support and setting sales volume, new energy auto companies should also be encouraged to develop self-sustaining and developed nationally-compliant businesses. Model to create an environment that encourages the use of electric vehicles, including building the necessary infrastructure and incentives to stimulate public demand, rather than just providing substantial subsidies and convenience for the purchase of electric vehicles; giving priority to promoting new energy sources in commercial operations that rely on large numbers of vehicles Cars, such as urban public transportation, taxi companies, and government official vehicles, rather than being concentrated on individual consumers, government procurement and corporate fleet orders will help open up the market for electric vehicles in China.

\section{Acknowledgements}

This work was financially supported by the Jiangsu province graduate student training innovation project for 2011 (070621), China institute of manufacturing development (SK20120200-9).

\section{References}

[1] Eva Horváthová. Does environmental performance affect financial performance? A metaanalysis[J]. Ecological Economics,2010,70(1).

[2] Andrea Guerrini, Giulia Romano, Bettina Campedelli. Factors affecting the performance of water utility companies[J]. International Journal of Public Sector Management,2011,24(6).

[3] Aigbe Akhigbe, James E. McNulty, Bradley A. Stevenson. How does transparency affect bank financial performance?[J]. International Review of Financial Analysis,2013,29.

[4] H. S. Rohitha Rosairo, Michael C. Lyne, Sandra K. Martin, Kevin Moore. Factors Affecting the Performance of Farmer Companies in Sri Lanka: Lessons for Farmer-Owned Marketing Firms[J]. Agribusiness,2012,28(4).

[5] Julia C. Naranjo-Valencia, Daniel Jiménez-Jiménez, Raquel Sanz-Valle. Studying the links between organizational culture, innovation, and performance in Spanish companies [J]. Revista Latino Americana de Psicología, 2016, 48(1).

[6] Qinxiu Zhang. Study on corporate social responsibility performance evaluation -- take guangdong manufacturing listed company as an example $[\mathrm{J}]$. Economic Research Guide,2017(02):10-13.

[7] Shaowen Luo. Research on the development strategy of China's new energy automobile industry [D].Fudan University, 2008.

[8] Yaoming Zeng, Zhongliang Shi. Comparative analysis on policies of new energy automobile industry at home and abroad [J]. Enterprise economy, 2011,30(02):107-109.

[9] Wang Tao.Recharging China’s Electric Policy [N].China Daily. 2013 :9

[10] Tessa T. Taefi, Jochen Kreutzfeldt, Tobias Held, Andreas Fink. Supporting the adoption of electric vehicles in urban road freight transport - A multi-criteria analysis of policy measures in Germany[J]. Transportation Research Part A,2016,91.

[11] Marcello Contestabile, Mohammed Alajaji, Bader Almubarak. Will current electric vehicle policy lead to cost-effective electrification of passenger car transport?[J]. Energy Policy,2017,110. 
[12] Timothy M. Sweda, Irina S. Dolinskaya, Diego Klabjan. Adaptive Routing and Recharging Policies for Electric Vehicles [J]. Transportation Science, 2017.

[13] Fei Xu. Study on financial performance evaluation of new energy automobile listed companies [D]. Harbin University of Science and Technology, 2015.

[14] Qingjiao Chen, Yukun Gai. Analysis on the performance and influencing factors of listed companies in business service industry is based on panel data from 2009 to 2013 [J]. The Theory and Practice of Finance and Economics,2015,36(03):78-83.

[15] Information on https://mini.eastday.com/a/180312231514468.html

[16] Beneki C,Papastathopoulos A.A log linear analysis of factors affecting performance of European manufacturing SEMs [J].International Journal of Management \&Marketing Research, 2011, 4(3):75-93.

[17] EUGENE F BRIGHAM, JOEL F HOUSTON. Fundamental of Financial Management [M]. $12^{\text {th }}$ Edition. Ohio: Cengage Learning, 2009:145-148.

[18] Yichi Sun. Study on financial performance evaluation of listed companies and its influencing factors [D].Liaoning University, 2011.

[19] STEM. J. M, G.BENNETT STEWART, DONALD. H. C. J. The EVA Financial Management System [J]. Bank of American Journal of Applied Corporate Finance, 1995, 6(12):32-46.

[20] BACIDORE J M, BOQUIST J A. The Search for the Best Financial Performance Measure [J]. Financial Analysis Journal, 1997, 53(3):10-11.

[21] KAPLAN.R.S, NORTON.D.P. The Balanced Scorecard-Measures that Drive Performance [J].Harvard Business Review, 1992, 14(2):7-19. 